\title{
Determinants of railway transport sustainability
}

\author{
Olha Kravchenko, ${ }^{1, *}$, and Nadiia Bohomolova ${ }^{1}$ \\ ${ }^{1}$ State University of Infrastructure and Technology, Kyiv, Ukraine
}

\begin{abstract}
The deepening of integration processes between the countries of Europe and Asia, the need for regular and mass passenger and freight traffic contributes to the increasing importance of transport systems. In this context, railway infrastructure, which ensures the uninterrupted operation of industrial complexes in many countries of the world and contributes to the development of international cooperation, acquires particular importance. This is also true for the railway transport of Ukraine, which is a connecting element between the transport systems of the EU, Russia and Asian countries. The paper substantiates that the sustainable functioning of railway transport is one of the necessary conditions for the development of national economies. The system of external and internal determinants of railway transport sustainability is highlighted. These determinants are analyzed on the example of railway transport in Ukraine. It is shown that external determinants form the basis of the functioning of railway companies, which also affects their internal determinants. Management of railway transport sustainability should be comprehensive, which will allow developing an effective set of preventive measures.
\end{abstract}

\section{Introduction}

One of the strategic directions for the development of the EU is to improve the relations between the countries of Europe and Asia. This is due to a significant turnover between them: in 2016, exports from the EU to Asia amounted to 618 billion euros (35\%) and imports - 774 billion Euros (45\%) [1]. Ensuring further interdependence and strengthening economic cooperation implies stable ties not only between countries, but also regions. This is impossible without a well-developed and efficient transport infrastructure that promotes economic growth, enhances the competitiveness of national economies, creates new jobs and, as a result, improves the quality of life of the population. In this context, systems involving international transport corridors are of a particular importance. Such systems include the railway transport of Ukraine, which can be considered as a connecting element between the transport systems of the EU, Russia and the Asian countries.

\section{Problem statement}

Railway transport forms the basis of the country's transport infrastructure and, thus, has a significant impact on the functioning of enterprises in other sectors. The study of the

\footnotetext{
* Corresponding author: kravch.olha@gmail.com
} 
functioning of rail transport in the context of ensuring the security of both national economies and mesoregions devoted to the publication by many scientists. Thus, the majority of researchers (Dugin and others) are in favor of uniting the Eurasian space through a developed and efficient transport system against thalassocratia (maritime countries), i.e. against a coalition of the Western countries led by the United States [2]. It is noted that the formation of such a system in the Eurasian region will allow each country to improve their own welfare, reduce the threat of terrorism and drug traffic, as well as implement the geopolitical goals of all countries of the Eurasian space [2, 3].

Based on an analysis of the countries of South and Southeast Asia, Zingel shows that transport, including railway transport, helps to reduce the development risks. He also notes that countries recognized as "failing or even failed" usually have poor infrastructure [4]. Sokolov, Kozhevnikov and Mezhokh noted that the level of development of transport is one of the factors ensuring the economic security of the country, both in terms of the complete geographical coverage of the country's territory by means of communication, as well as in terms of the technical and technological level of development of certain types of transport, the harmoniousness of their interaction, compliance with the development of productive forces of the state [5]. Kharlamova also notes that the transport system provides basic living conditions for society and serves as an important tool for achieving social, economic and the foreign policy goals. In addition, historically, the development of transport largely predetermines the economic and spatial development of countries, helps to strengthen their integrity and international influence [6]. Polzin emphasizes that a safe transportation system is one of the decisive factors of national security, including in the fight against terrorism [7]. In addition, transport, including railway transport, is considered as an integral element of the national security strategies in many countries of Europe and Asia [8-10 and others]. This actualizes the problem of ensuring the sustainable functioning of both the transport infrastructure as a whole and its individual sectors. The solution of this problem should be based on the institutional features of a particular country, as well as the degree of their influence on the state and level of infrastructure development.

In the context of increasing interdependence between the countries of Europe and Asia, the transport system of Ukraine is of particular importance, which has significant transit potential due to its advantageous geographical location and developed infrastructure. The basic transport sector is rail transport, which is in the process of reforming and has a direct impact on the economic security of Ukraine, as well as of neighboring countries. Therefore, the purpose of this study is to identify and analyze the determinants of a sustainable functioning of the rail transport.

\section{Finding}

At the European Conference of EU Transport Ministers, the criteria for classifying the transport system as sustainable and, as a result, effective were identified. These criteria relate primarily to the production activities of individual transport sectors, namely the provision of [11]: (i) equal access to transport infrastructure and meeting the needs of individuals, companies and society as a whole in transportation; (ii) clear and effective work, as well as a rational tariff policy as necessary conditions for the functioning of companies, maintaining the competitiveness of the economy, as well as ensuring a balanced regional development; and (iii) minimize the harmful effects on the environment.

The implementation of these criteria also implies an increased attention to the issues of not only the economy of individual transport sectors as a reflection of the effectiveness of their operations, but also of financial support for their development. Therefore, it seems necessary to comprehensively study the factors (determinants) that affect their current 
functioning and development opportunities, taking into account the peculiarities of production, economic and financial activities.

\subsection{External determinants of railway transport sustainability}

Rail transportation has a number of advantages, which determined their primary development in the past and the "renaissance" in the present. Thus, railway transport is universal (the ability to transport almost all types of cargo and passenger categories), has a high carrying capacity (a double-track electrified railway can carry up to 150-200 train pairs per day and provide more than 100 million tons of cargo in each direction), the relatively low cost of transport (as opposed to air and sea), relatively free accommodation (the construction of railways in almost any territory), regularity (the ability to carry out rhythmically transportation at all times of the year and in fact not to depend on the natural conditions, unlike river and sea transport), a relatively high speed of movement, and reliability.

The external determinants of the functioning and development of the railway sector are formed both by the institutional and macroeconomic environment. The difficulty of accounting for these determinants is manifested in the fact that transport companies cannot directly influence them, but only adapt to the changes that are taking place. One of these determinants is the level of development of the national economy. This is due to the fact that transport products are transport services for the movement (transportation) of goods and passengers and is not a new product that can be separated from the production process and participate in the economic turnover in a tangible form as a commodity. Transport products act as a beneficial effect from the work of transport, which can be consumed only during the production process and does not exist as a consumable item different from this process. The consequence of this is a steady correlation between the dynamics of freight traffic and the growth rate of industrial output (Fig. 1), which can be explained by a fairly stable nomenclature of rail freight traffic.

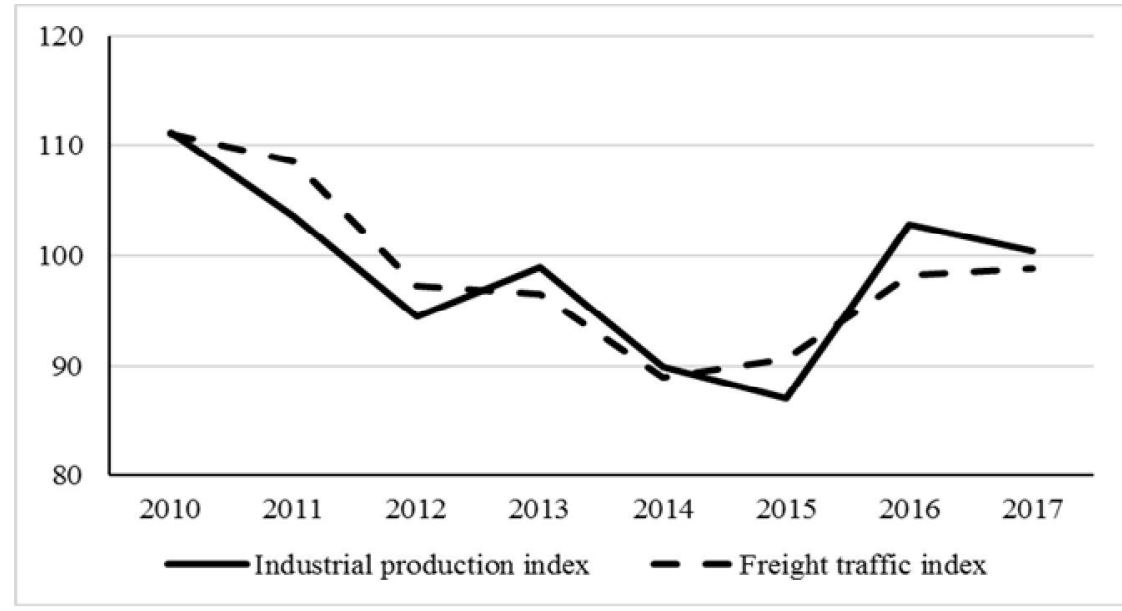

Fig. 1. Dynamics of industrial production and freight traffic (railway transport of Ukraine; correlation coefficient 0.912 ).

Source: built and calculated by the authors based on [12].

As for passenger traffic, it is also quite stable and its volume depends on the solvency of the population and employment opportunities. Thus, according to opinion polls, more than $45 \%$ of all passengers use rail transport almost daily, while more than $41 \%$ of commuter train passengers travel to work and study. In the long-distance (long-distance and 
international) traffic, $35 \%$ of passenger trips are related to visits from relatives and friends, $33 \%$ from business trips, and $21 \%$ from trips to places of recreation [13].

Another external determinant for the railway sector is the participation of the government in financing passenger transport and infrastructure maintenance. This is due to the fact that (iii) European railways are either owned by the state, or the state has a controlling stake; (ii) EU states actively regulate the activities of the national railway companies; (iii) states subsidize the functioning of the railway sector (subsidies for many railways account for more than 50\% [14]); (iv) railway infrastructure is not attractive for private investors; (v) railway companies solve economic, social and military tasks, often without sufficient financial compensation of the state. The railway infrastructure of Ukraine is state-owned and the state shifts its social obligations for passenger traffic and the provision of preferences to individual companies and industries in general without adequate compensation. This not only has no contribute to the sustainability of rail transport, but also hinders its modernization.

The influence of the political and socio-economic situation in the country also significantly affects the sustainability of rail transport. An illustrative example is the example of Ukraine, which due to the hostilities in the Donbass lost $3.0 \%$ of the railway infrastructure [15], which served the most developed industrial region of Ukraine. This resulted in significant losses for the national economy due to a decrease in industrial production in 2014 by $11.1 \%$, in 2015 - by $9.4 \%$. This trend continues to this day.

The own losses of Ukrzaliznytsya JSC were also significant: the restoration of the destroyed railway infrastructure in 2014 was estimated at more than 900 million UAH. The situation is complicated by the fact that the loss of traffic on the Donetsk railway is multiplied for the entire Ukrzaliznytsya JSC, which led to a threefold decrease in performance across the entire railway network. The result was a loss of 15.4 billion UAH [15]. Since 2014, the situation continues to deteriorate due to the increased instability in the country, deterioration of relations with traditional partners, the lack of a rational government strategy in the development of the national infrastructure.

The external determinants form the basis of the functioning of transport enterprises, including the railway, which has an impact on their internal determinants.

\subsection{Internal determinants of rail transport sustainability}

The effect of external factors is also enhanced by internal ones, the negative impact of which at the moment is no less significant and at a certain moment can "override" positive changes in the macroeconomic environment. The management of Ukrzaliznytsya JSC recognizes 5 groups of risks that can have a significant impact on its activities, namely (1) economic risks (risk of a decrease in freight traffic); (2) significant investment needs (relatively high level of deterioration of infrastructure and rolling stock); (3) staff costs (a large proportion of staff costs in operating costs); (4) currency risk (part of expenses and liabilities denominated in the foreign currency); (5) refinancing risk and interest rate risk [15]. However, the results of the public audit and data of the consolidated reporting show that this list of threats does not correspond to the current situation in Ukrzaliznytsya, JSC.

At the moment, risk factors that have a key impact on the level of production, economic and financial stability of Ukraine's railway transport are: the lack of effective institutional transformations of the industry, the state of non-current assets, deterioration of financial condition, low investment activity.

Institutional changes in the railways of Ukraine should have taken place in the process of its reform. However, as repeatedly noted by researchers and practitioners, the changes that have occurred are inconsistent and irrational due to the lack of a state long-term transport strategy, excessive state intervention in the activities of Ukrzaliznytsya, 
ineffective top management, high levels of corruption etc. quality indicators of the industry. The result was a rapid deterioration in the quantitative and qualitative indicators of the industry.

Non-current assets of Ukrzaliznytsya JSC at the end of 2017 accounted for $94.3 \%$ of the total amount of its assets, including fixed assets - 69.2\%, the depreciation of which according to the financial statements is on average 59.1\% [15] with actual physical and moral wear and tear of more than $90 \%$ (electric fleet wear - 95.7\%, diesel locomotives $99.7 \%$ ). In addition, $31 \%$ of the fleet of electric locomotives and $44 \%$ of the fleet of diesel locomotives are out of order [16]. Such a condition of fixed assets creates a real threat not only of emergency situations in the process of transporting goods and passengers, but also the actual withdrawal of certain sections of the network from service, which will lead to a violation of the integrity of the railway network.

In 2017, Ukrzaliznytsya JSC received a net financial result in the amount of UAH 114.5 million. However, this did not happen as a result of an increase in traffic volumes and the provision of services, but rather an increase in tariffs and a decrease in gross expenditures as a result of non-compliance with the capital investment plan. At the end of 2017, longterm liabilities and collateral amounted to 30.0 billion UAH, and short-term liabilities amounted to 23.7 billion $\mathrm{UAH}$, that is, there is a problem not only of poor performance, but also of reduced solvency and financial stability, resulting in a technical default in 2016. This problem is aggravated by the fact that more than $90 \%$ of the capital investment of Ukrzaliznytsya JSC is financed with its own funds.

Under the conditions of a critical deterioration in the financial state, corruption, first of all, in the tender sphere becomes one of the factors reducing the level of sustainability of Ukrzaliznytsya JSC, since it leads to systematic leaching of funds from its economic turnover. The transition of tenders to the ProZorro system did not significantly change the situation.

In 2017, the management of Ukrzaliznytsya JSC presented an investment plan for the development of the railway sector for 2017-2021. This plan provides for investments in the amount of $\$ 5.8$ billion, including the purchase of rolling stock - $\$ 3.2$ billion, its modernization - $\$ 709$ million, and infrastructure development - $\$ 1.9$ billion (Table 1).

Table 1. Investment plan of Ukrzaliznytsya JSC.

\begin{tabular}{|l|c|c|c|c|}
\hline & Current state, units & \multicolumn{3}{|c|}{ Elements of the investment plan } \\
\cline { 3 - 5 } & $\begin{array}{c}\text { Purchase, } \\
\text { units }\end{array}$ & $\begin{array}{c}\text { Modernization, } \\
\text { units }\end{array}$ & $\begin{array}{c}\text { Cost, million } \\
\text { dollars }\end{array}$ \\
\hline Locomotives & 3.9 & 262 & 798 & 1,667 \\
\hline $\begin{array}{l}\text { Freight wagons, } \\
\text { thousand }\end{array}$ & $\begin{array}{c}82.5 \\
\text { (working park - 62.9) }\end{array}$ & 34.6 & 46.02 & 1,309 \\
\hline $\begin{array}{l}\text { Passenger cars, } \\
\text { thousand }\end{array}$ & $\begin{array}{c}4.6 \\
\text { (working park - 3.1) }\end{array}$ & 419 & 596 & 541 \\
\hline
\end{tabular}

Source: compiled by the authors based on [16].

Not only the future state of the railway network, but also its current sustainability will depend on the implementation of this investment plan. However, in 2018, Ukrzaliznytsya, JSC made capital investments in the amount of 16.9 billion UAH ( $\$ 610$ million), which made it possible to reconstruct $309 \mathrm{~km}$ of the track (at the same time, at the beginning of 2019,3460 sections of routes with a total length of $1,857 \mathrm{~km}$ were closed due to extremely unsatisfactory condition), as well as overhaul of 130 locomotives and 3.5 thousand freight cars, 126 passenger cars were updated, and 15 locomotives were purchased. Such volumes of capital investments are insufficient, since the annual investment needs amount to about 30 billion UAH annually. 


\section{Conclusions}

Ensuring production, economic and financial sustainability of rail transport should be comprehensive and involve the implementation of a set of measures aimed not only at improving the efficiency of its activities, but also the introduction of a rational reform program. Further study of this problem should be aimed at a model study of the degree of influence of both individual determinants and their interaction on the current and future sustainability of the railway sector. As a tool for such a study, simulation modeling can be used. Building and analyzing a set of interrelated simulation models will not only correctly assess the possible level of threats to the sustainable operation of rail transport and, as a result, the national economy as a whole, but also develop a set of preventive measures to level the negative impact of changes in external and internal determinants.

\section{References}

1. European commission. Connecting Europe and Asia: Building blocks for an EU Strategy. Retrieved from: https://eeas.europa.eu/headquarters/headquartershomepage/50724/connecting-europe-and-asia-building-blocks-eu-strategy_en (2018).

2. A.G. Dugin, Geopoliitika bases. Moscow: "ARKTOGEYA-tsentr" (2000).

3. E. Zenkina, V. Kutovoi, Transport system and its impact on the sustainable development of the russian economy. Economy: Problems, Solutions and Perspectives, 2, 95-100. DOI 10.26425/1816-4277-2019-2-95-100 (2019).

4. W-P Zingel, National Security and Economic Development: Securing Development Developing Security. Retrieved from: http://www.bundesheer.at/pdf_pool/ publikationen/eco_impacts_02_national_security_zingel.pdf (2009).

5. Yu.I. Sokolov, R.A. Kozhevnikov, Z.P. Mezhokh, Russian transport business, 6, 10-13 (2016).

6. Yu.A. Kharlamova, Problems of National Strategy, 1(10), 113-128 (2012).

7. S.E. Polzin, Security Considerations in Transportation Planning. Retrieved from: https://www.planning.dot.gov/documents/SecurityPapers/SecurityConsiderations_Polzi n.htm (2002).

8. National Security Strategy of the Republic of Poland Retrieved from: https://www.bbn.gov.pl/ftp/dok/NSS_RP.pdf (2014).

9. National Security Strategy of the Republic of Hungary. https://www.files.ethz.ch/isn/.../Hungary_English-2004.pdf (2004).

10. India's National Security Strategy. Retrieved from: https://manifesto.inc.in/pdf/national_security_strategy_gen_hooda.pdf (2019).

11. Sustainable Transportation and TDM. Planning That Balances Economic, Social and Ecological Objectives. Retrieved from: https://www.vtpi.org/tdm/tdm67.htm (2017).

12. State Statistics Service of Ukraine. Retrieved from: http://www.ukrstat.gov.ua/ (20102017).

13. N.P. Teroshina, V.G. Galaburda, M.F. Trikhunkov, Economy of rail transport. Moscow: UMTs ZhDT (2006).

14. J. Drew, European railway reform and performance. The Voice of European Railways, $25^{\text {th }}$ March (2009).

15. State Administration of Railway Transport of Ukraine "Ukrzaliznytsia". Retrieved from: http://www.uz.gov.ua/ (2014).

16. Actual problems of Ukrzaliznytsia and possible ways of their solution. Public Audit. Retrieved from: http://publicaudit.com.ua/reports-on-audit/aktualni-problemiukrzaliznitsi-ta-mozhlivi-shlyahi-yih-virishennya/ (2017). 